\title{
Remediation of Heavy Metal Contaminated Soil Using Potential Microbes Isolated from a Closed Disposal Site
}

\author{
Fauziah S. H. ${ }^{1,2 *}$, Jayanthi B. ${ }^{1}$, Emenike C. U. ${ }^{1,2}$, Agamuthu ${ }^{1,2}$ \\ ${ }^{1}$ Institute of Biological Sciences, Faculty of Science, University of Malaya, 50603 Kuala Lumpur, Malaysia. \\ 2 Center for Research in Waste Management, Faculty of Science, University of Malaya, 50603 Kuala Lumpur, \\ Malaysia. \\ * Corresponding author. Tel.:+603 7967 6739; email: fauziahsh@um.edu.my \\ Manuscript submitted January 10, 2017; accepted March 8, 2017. \\ doi: 10.17706/ijbbb.2017.7.4.230-237
}

\begin{abstract}
Soil environment is a major sink for a multitude of chemicals and heavy metals, which inevitably leads to environmental contamination problems. Various human activities including agricultural, urban or industrial, or landfilling are major contributors to heavy metal contamination in the environment. Since landfilling is one of the ultimate waste disposal methods, the generation of leachate is inevitable. Leachate from landfill is highly heterogeneous and consist high amount of heavy metal. Subsequent movement of the leachate into the surrounding soil, ground water or surface water could lead to severe pollution problems to and cause toxicity to human and other living organisms. Microorganisms has the ability to solubilize the metals (or increase their bioavailability) via the production of siderophores and adsorb the metals in their biomass on metal-induced outer membrane proteins and by bio precipitation. Therefore this study aimed to remediate heavy metal in leachate contaminated soil from a closed non-sanitary landfill in Kuala Lumpur. Preliminary soil and leachate characterization revealed high amount of metal contaminants as compared to the prescribed limit by local and international standard. Total of eighteen microbes were isolated from the contaminated site and were grouped into two treatments, proteobacteria and non-proteo bacteria. Comparison between the treatments revealed that proteobacteria (Treatment A) were performing higher metal removal activity compared to non- proteobacteria (Treatment B) and control (Treatment C). Out of four metals tested in this study, three of the metals (As (71.86\%), Ni (50.8\%), Al (87.15\%)) were removed significantly by the addition of Treatment A. Highest metal removal rate constant was obtained for Al at 0.02 day $^{-1}$. Therefore, it can be concluded that the addition of microbes, namely proteobacteria to leachate contaminated soil can remove the heavy metal content at a significant rate.
\end{abstract}

Key words: Leachate, proteobacteria, metal removal capacity, bioattenuation, bioremediation.

\section{Introduction}

Current global municipal solid waste generation is approximately 1.3 billion tonnes per year, and are expected to increase to approximately 2.2 billion tonnes per year by 2025 . Landfilling is one of common waste disposal practice in the world that makes landfills the essential facilities for the waste management sector. Most of the landfills in Malaysia are non-sanitary and this poses serious threats to the local environment. Improper waste disposal will pollute the environment and risk the spread of waste borne diseases. In addition, landfilling activities emit leachate and landfill gases.

Leachate is a liquid product produced by action of leaching when the rain water percolates through any 
permeable material [1]. If leachate is not properly collected it will flow or migrate to other water bodies. Leachate is produced over time, and with the percolation of rain water, the degradable fractions of the waste decompose and the resulting products are diluted and dispersed into the underlying soil if a site is not contained.

Leachate contains more than 200 types of elements or where more than 35 are heavy metals (arsenic, cadmium, cobalt, chromium, copper, mercury, manganese, nickel, lead, tin, and thallium), which have potential to harm the environment and human health [2]. Heavy metals are significant environmental pollutants and their toxicity is a problem of increasing significance for ecological, evolutionary, nutritional and environmental reasons [3], [4].

Heavy metals disrupt metabolic functions in human being in two ways: it accumulates and thereby disrupts function in vital organs and glands such as the heart, brain, kidneys, bone, liver, etc; displaces the vital nutritional minerals from their original place and thereby, hindering their biological functions [5]. U. S .Environment Protection Agency and International Agency for Research on Cancer classified this heavy metals to be human carcinogenic. Due to the toxicity effect, a remediation option is necessary to overcome and clean the contaminated soil.

Bioremediation techniques are effective and efficient method for remediation of pollutants. In an effective bioremediation process, microorganisms will enzymatically attack the pollutants and convert them to harmless products through chemical, physical and biological [6].

Environmental conditions permit microbial growth and activity, its application often involves the manipulation of environmental parameters to allow microbial growth and degradation to proceed at a faster rate. These factors include the existence of a microbial population capable of degrading the pollutants, the availability of contaminants to the microbial population, and the environmental factors.

The aim of this study are to remediate heavy metal contaminated soil using two different groups of treatment isolated from a non-sanitary closed landfill and to compare their removal capacity.

\section{Materials and Methods}

\subsection{Soil and Leachate Characterization}

Soil samples were obtained from a closed non-sanitary disposal site i.e. Taman Beringin Landfill (TBL) in Kuala Lumpur, Malaysia. This disposal site has been closed since 2000, but leachate is still oozing out from the closed waste cells.

This closed site lacks of any lining system to prevent penetration of leachate into the groundwater system. Nevertheless, systematic capping layers are in place when the site undergone its closure phase. Currently, the disposal site is closely monitored to prevent further environmental degradation to the surrounding.

Soil samples were excavated at $30 \mathrm{~cm}$ depth in accordance with the 2014 ASTME-1197 [6], [7]. The samples were analyzed for $\mathrm{pH}$ using a multiprobe meter (YSI Professional Plus, USA), while the soil total nitrogen, total potassium, and total phosphorus were analyzed by adopting ASTM E778-87, ASTM E96-94, and ASTM D5198-92 methods, respectively. Elemental concentrations of metals in the soil were analyzed based on the USEPA 3050B guidelines except for mercury (Hg), which was analyzed based on the USEPA 3052 method.

All assessments were duly replicated (including different trials). Similarly, the raw leachate samples were collected from the environment and analyzed for parameters similar to the soil samples. Physico-chemical properties of the leachate samples determined in the laboratory were $\mathrm{BOD}_{5}, \mathrm{COD}$, total $\mathrm{N}, \mathrm{P}, \mathrm{K}$, and the metal distribution. The assessment was conducted based on APHA (1998) standards [7].

\subsection{Bacterial Isolation and Identification}

Bacterial species were isolated by mixing $1 \mathrm{~g}$ of soil sample with $10 \mathrm{ml}$ of normal saline water $(0.9 \% \mathrm{NaCl})$ 
as stock. The mixture was shaken vigorously ( $3 \mathrm{~h}$ at $180 \mathrm{rpm}$ ) with the aid of a Lab-line 3521 orbital shaker, and the resulting suspension was subjected to 20 times serial dilution. Dilutions $(0.1 \mathrm{ml})$ were dispensed on freshly prepared nutrient agar under aseptic conditions. The inoculated media plates and associated replicates were incubated at $37^{\circ} \mathrm{C}$ for $24 \mathrm{~h}$.

Developed colonies were further sub-cultured to ensure the purity of samples prior to identification. Subsequently, the Biolog GEN III Microplate protocol was used to test the isolated microbes. An Omni log reader was used to identify the species of bacteria contained in the microbial identification system software.

\subsection{Microbial Formulation for Bioremediation of Heavy Metal Contaminated Soil}

Microbial consortia used in this study consist of eighteen (18) strains isolated using the method stated above. Individual strain was first grown in Nutrient Agar at $33^{\circ} \mathrm{C}$ for 2 days and then inoculated to Nutrient Broth and grown to achieve stationary phase in shaker at 150rpm. After the individual strain achieved growth of $1.3 \mathrm{ABS}$ at $600 \mathrm{~nm}$ wavelength, the strains were pooled in equal proportions [7].

\subsection{Bioremediation Experimental Design}

The leachate contaminated soil from TBL was collected for the bioremediation study. The experiment consisted of three treatments namely; Treatment A to be treated with proteobacteria, Treatment B to be treated with non-proteobacteria and Treatment $\mathrm{C}$ was the control experiment.

The experiment was carried out with $2 \mathrm{~kg}$ of leachate contaminated soil amended with $10 \% \mathrm{v} / \mathrm{v}$ of microbial inoculum. Each treatment consisted of about $\left(3 \times 10^{9} \mathrm{CFU} / \mathrm{g}\right)$ of inoculum, and the experiment was conducted in triplicates for all treatments. Soil moisture was maintained by adding water regularly to ensure $60-65 \%$ moisture content.

\subsection{Heavy Metal Analysis}

Soil heavy metal concentration was analysed every 20 days for all the treatment using ICP-OES according to USEPA 3050B guidelines [7].

\subsection{Rate Constant of Heavy Metal Removal}

Rate of metal uptake in a day was calculated using first order kinetic models:

$$
K=-\frac{1}{t}\left(\ln \frac{C}{C_{0}}\right)
$$

$\mathrm{K}=$ first-order rate constant for metal uptake per day

$\mathrm{t}=$ time in days

$\mathrm{C}=$ concentration of residual metal in the soil $\left(\mathrm{mg} \mathrm{kg}^{-1}\right)$

$\mathrm{C}_{0}=$ initial concentration of metal in the soil $\left(\mathrm{mg} \mathrm{kg}^{-1}\right)$

\section{Results and Discussion}

The characterization of heavy metal in leachate and soil from TBL is indicated in Table 1 and Table 2. Heavy metal concentration in landfill leachate and soil at TBL exceeded the prescribed limits from Department of Environment, Malaysia and International Standards.

The soil heavy metal concentrations (Table 2) in the soil follow the order of $\mathrm{Al}(49600 \mathrm{mg} / \mathrm{kg})>\mathrm{Fe}$ $(42900 \mathrm{mg} / \mathrm{kg})>\mathrm{Mn}(281 \mathrm{mg} / \mathrm{kg})>\mathrm{As}(141 \mathrm{mg} / \mathrm{kg})>\mathrm{Cu}(59 \mathrm{mg} / \mathrm{kg})>\mathrm{Zn}(49 \mathrm{mg} / \mathrm{kg})>\mathrm{Cr}(46 \mathrm{mg} / \mathrm{kg})>\mathrm{Ni}(21$ $\mathrm{mg} / \mathrm{kg})>\mathrm{Pb}(18 \mathrm{mg} / \mathrm{kg})$.

The high metal concentration in landfills is mainly due to the nature of solid waste dumped in the landfill. 
The sources of heavy metal in the site probably include metal scraps, blades, and pharmaceuticals, galvanizing materials, paints, pigments, insecticides and cosmetics along with garbage.

The distribution of metal among specific forms varies widely based on the metal's chemical properties and soil characteristics. Therefore, the contaminated soil was further studied for remediation with the inoculation of proteobacteria and non-proteobacteria for selected heavy metal.

Table 1. Leachate Characterization of Taman Beringin Landfill

\begin{tabular}{lllll}
\hline \hline Analysis & Method & Unit & $\begin{array}{l}\text { Taman Beringin Leachate } \\
\text { characteristics }\end{array}$ & $\begin{array}{l}\text { Standard (Environmental Quality } \\
\text { Regulations 2009, Malaysia) }\end{array}$ \\
\hline $\mathrm{pH}$ & & & $7.57 \pm 0.8$ & $6.0-9.0$ \\
\hline $\mathrm{BOD}$ & APHA 5210 B & $\mathrm{mg} / \mathrm{L}$ & $127 \pm 45$ & 20 \\
\hline $\mathrm{COD}$ & APHA 5220 & $\mathrm{mg} / \mathrm{L}$ & $482 \pm 103$ & 400 \\
\hline Total N & ASTM E778-87 & $\%$ & $0.25 \pm 0.08$ & 5 \\
\hline Total $\mathrm{K}$ & ASTM E926-94 & $\mathrm{mg} / \mathrm{L}$ & $11.6 \pm 2.1$ & $\mathrm{~N} . \mathrm{A}$ \\
\hline $\mathrm{Total} \mathrm{P}$ & ASTM D5198-92 & $\mathrm{mg} / \mathrm{L}$ & 0.1 & $\mathrm{~N} . \mathrm{A}$ \\
\hline $\mathrm{As}$ & USEPA 3050 B & $\mathrm{mg} / \mathrm{L}$ & 0.01 & 0.05 \\
\hline $\mathrm{Ca}$ & USEPA 3050 B & $\mathrm{mg} / \mathrm{L}$ & $242.1 \pm 42$ & $\mathrm{~N} . \mathrm{A}$ \\
\hline $\mathrm{Fe}$ & USEPA 3050 B & $\mathrm{mg} / \mathrm{L}$ & $134.6 \pm 16$ & 5.0 \\
\hline $\mathrm{Mn}$ & USEPA 3050 B & $\mathrm{mg} / \mathrm{L}$ & $3.1 \pm 0.32$ & 0.2 \\
\hline $\mathrm{Mg}$ & USEPA 3050 B & $\mathrm{mg} / \mathrm{L}$ & $52.2 \pm 8.7$ & $\mathrm{~N} . \mathrm{A}$ \\
\hline $\mathrm{Na}$ & USEPA 3050 B & $\mathrm{mg} / \mathrm{L}$ & $29.7 \pm 5.1$ & $\mathrm{~N} . \mathrm{A}$ \\
\hline $\mathrm{Cu}$ & USEPA 3050 B & $\mathrm{mg} / \mathrm{L}$ & $0.5 \pm 0.1$ & 0.2 \\
\hline $\mathrm{Zn}$ & USEPA 3050 B & $\mathrm{mg} / \mathrm{L}$ & $24.3 \pm 3$ & 2.0 \\
\hline $\mathrm{Pb}$ & USEPA 3050 B & $\mathrm{mg} / \mathrm{L}$ & $<0.01$ & 0.10 \\
\hline $\mathrm{Cd}$ & USEPA 3050 B & $\mathrm{mg} / \mathrm{L}$ & $0.4 \pm 0.1$ & 0.01 \\
\hline $\mathrm{Hg}$ & USEPA 3052 & $\mathrm{mg} / \mathrm{L}$ & 0.03 & 0.005 \\
\hline $\mathrm{Cr}$ & USEPA 3050 B & $\mathrm{mg} / \mathrm{L}$ & $6.2 \pm 1.4$ & 0.20 \\
\hline $\mathrm{Ni}$ & USEPA 3050 B & $\mathrm{mg} / \mathrm{L}$ & $0.85 \pm 0.1$ & 0.20 \\
\hline $\mathrm{Al}$ & USEPA 3050 B & $\mathrm{mg} / \mathrm{L}$ & $5.47 \pm 1.2$ & $\mathrm{~N} . \mathrm{A}$ \\
\hline \hline
\end{tabular}

Table 2. Characteristics of Soil from Taman Beringin Landfill

\begin{tabular}{llll}
\hline \hline Test parameter & Units & Test method & Taman Beringin landfill \\
\hline $\mathbf{p H}$ & & & 7.57 \\
Total N & $\%$ & ASTM E778-87 & 0.62 \\
Total K & $\mathrm{mg} / \mathrm{kg}$ & ASTM E926-94 & 396.9 \\
Total P & $\mathrm{mg} / \mathrm{kg}$ & ASTM D5198-92 & 568 \\
$\mathbf{A s}$ & $\mathrm{mg} / \mathrm{kg}$ & USEPA 3050 B & 141 \\
$\mathbf{C a}$ & $\mathrm{mg} / \mathrm{kg}$ & USEPA 3050 B & 1608 \\
$\mathbf{F e}$ & $\mathrm{mg} / \mathrm{kg}$ & USEPA 3050 B & 42900 \\
$\mathbf{M n}$ & $\mathrm{mg} / \mathrm{kg}$ & USEPA 3050 B & 281 \\
$\mathbf{M g}$ & $\mathrm{mg} / \mathrm{kg}$ & USEPA 3050 B & 127.2 \\
$\mathbf{N a}$ & $\mathrm{mg} / \mathrm{kg}$ & USEPA 3050 B & 4.54 \\
$\mathbf{C u}$ & $\mathrm{mg} / \mathrm{kg}$ & USEPA 3050 B & 59 \\
$\mathbf{Z n}$ & $\mathrm{mg} / \mathrm{kg}$ & USEPA 3050 B & 49 \\
$\mathbf{P b}$ & $\mathrm{mg} / \mathrm{kg}$ & USEPA 3050 B & 18 \\
$\mathbf{C d}$ & $\mathrm{mg} / \mathrm{kg}$ & USEPA 3050 B & $<0.01$ \\
$\mathbf{H g}$ & $\mathrm{mg} / \mathrm{kg}$ & USEPA 3052 & $<0.02$ \\
$\mathbf{C r}$ & $\mathrm{mg} / \mathrm{kg}$ & USEPA 3050 B & 46 \\
$\mathbf{N i}$ & $\mathrm{mg} / \mathrm{kg}$ & USEPA 3050 B & 21 \\
$\mathbf{A l}$ & $\mathrm{mg} / \mathrm{kg}$ & USEPA 3050 B & 49600 \\
\hline \hline
\end{tabular}

The microbes isolated from soil collected from TBL are listed in Table 3. The microbes were divided into 
proteobacteria and non-proteobacteria for the bioremediation experiment set up (Treatment A, B and C (Control)).

Microorganisms use numerous means to control intracellular metal levels. It includes various influx and efflux mechanisms and metal complexation by cellular components.

According to Emenike et al [7], the grouping of bacteria is expected to increase the metabolic potential of microbes towards heavy metal. Adsorption, precipitation, and organic binding are considered to be the major mechanisms responsible for removal of heavy metal in samples.

Table 3. Bacterial Treatments for Bioremediation Experiment

\begin{tabular}{cc}
\hline \hline Treatment A & Treatment $\mathbf{B}$ \\
\hline Ochrobacterium intermedium & Cloacibacterium $\mathrm{sp}$ \\
Burkholderia vietnamiensis & Chryseobacterium gleum \\
Stenotrophomonas acidaminiphilia & Bacillus aryabhattai \\
Acidovorax ebreus & Rhodococcus rubber \\
Brevundimonas diminuta & Bacillus Pumilus \\
Delftia tsuruhatensis & Bacillus kochii \\
Aeromonas caviae & Janibacter hoylei \\
Pseudomonas alcaligenes & Bacillus cereus \\
Pseudomonas mendocina & - \\
Serratia marcescens marcescens & - \\
\hline \hline
\end{tabular}

* Treatment $\mathrm{C}$ is the control experiment without addition of bacteria

Heavy metal remediation were carried out with the three different treatments namely, Treatment A, B and C, for 100 days as indicated in Fig. 1- 4. Arsenic (As) concentration from day 0 - 100 is showed in Fig. 1. As concentration at Day 0 was $141 \mathrm{mg} / \mathrm{kg}$ and after 100 days of remediation set up, Treatment A showed highest metal removal.

Treatment A reduces $71.8 \%$ of extractable As from the contaminated soil, followed by Treatment B (66.9\%) while Treatment $C$ which acts as control in this experiment reported to remove $60.7 \%$ of As. Both Treatment $A$ and Treatment $B$ have significantly removed As from the contaminated at $P>0.05$.

Fig. 2 shows the $\mathrm{Zn}$ concentration across 100 days. Initial $\mathrm{Zn}$ concentration in the contaminated soil from TBL was $49 \mathrm{mg} / \mathrm{kg}$. Treatment B demonstrated highest removal for $\mathrm{Zn}$ as compared to Treatment B and Treatment C.

Treatment B removed $50.3 \%$, Treatment A $47.6 \%$ and Treatment C removed only $25.85 \%$ of $\mathrm{Zn}$ from the leachate contaminated soil. Significant difference at P> 0.05 between addition of treatment A and B compared to Treatment $\mathrm{C}$ was observed in this study.

Significant difference between the treatments observed in this study proved that, microbes have a undiscovered and unexplored potential for the remediation of metal in the soil, which is evident when microbial inoculum as in Treatment $\mathrm{A}$ and $\mathrm{B}$ almost doubled the removal capacity as compared to Treatment $\mathrm{C}$, the control.

The remediation of Ni from contaminated soil is depicted in Fig. 3. For Ni, higher removal activities were observed with addition of Treatment A whereby $50.8 \%$ of $\mathrm{Ni}$ was successfully removed, followed by Treatment B (46\%) and Treatment C (44.4\%).

Variance in the heavy metal removal by different groups can be due to the fact that some microbe tends to be more specific and sensitive to one metal but have higher tolerance to other metals. Microbiological processes in the soil can either solubilize metals, thereby increasing their bioavailability and potential toxicity, or immobilize them, and thereby reduce the bioavailability of metals. These biotransformations are important components of biogeochemical cycles of metals exploited in bioremediation of metal contaminated soils [8]. Proteobacteria group appeared to be associated positively with heavy metal removal. 
It associated with in situ microbial community and suggests possible roles of these bacteria [9].

Fig. 4 shows the reduction of the $\mathrm{Al}$ concentration in the remediation study. Treatment $\mathrm{A}$ removed $89.15 \%$ of $\mathrm{Al}$, Treatment $\mathrm{B}$ removed $86.43 \%$ of $\mathrm{Al}$ and Treatment $\mathrm{C}$ removed $84.59 \%$ of $\mathrm{Al}$ from the initial concentration of $49600 \mathrm{mg} / \mathrm{kg}$. The removal activities for Al were very high as compared to other heavy metals studied. According to Kuddus et al [10], a bioremediation activity has successfully occurs when $65 \%$ or more heavy metals were removed from the system.

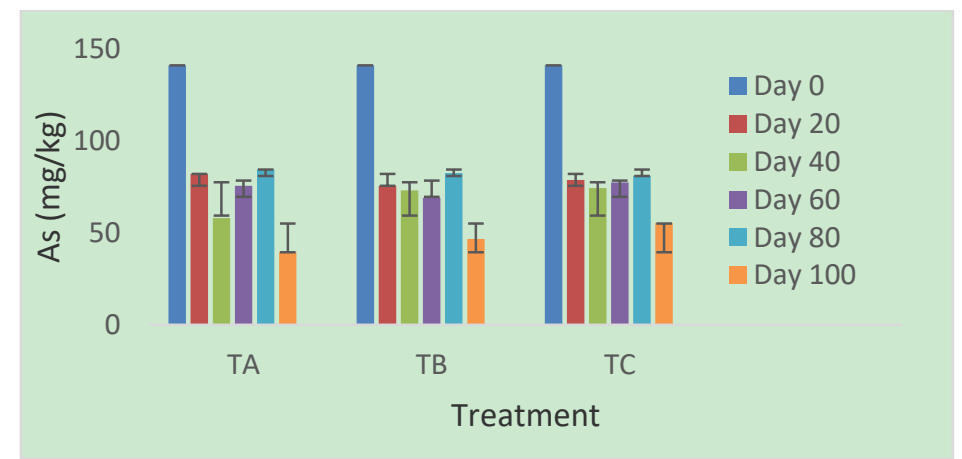

Fig. 1. Arsenic concentration across time with different treatments.

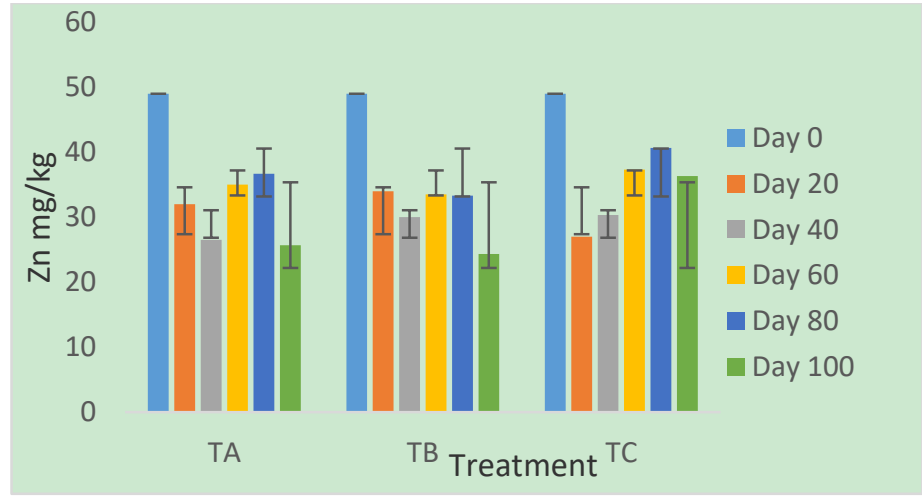

Fig. 2. Zinc concentration across time with different treatments.

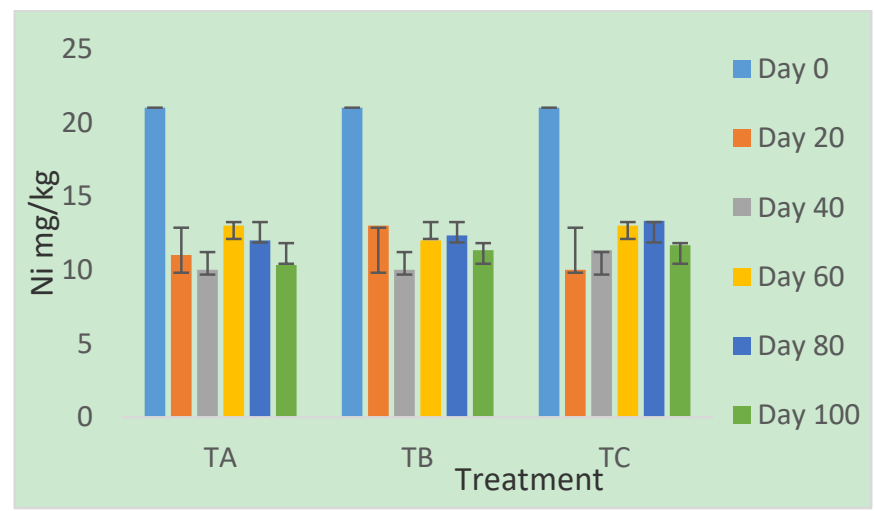

Fig. 3. Nickel concentration across time with different treatments.

Based on the heavy metal removal activity, the treatment amended with proteobacteria and non-proteobacteria revealed higher heavy metal removal activity than the control experiment. However the control, Treatment $\mathrm{C}$ shows a decrease in the heavy metal concentration which can be due to the natural bio attenuation activity [7]. The rate of removal of selected heavy metals is shown in Table 4.

Between the three different treatments, across different metals, the highest removal rate was found in 
Treatment A for Al. The removal rate was at 0.02 day-1. This implies that proteobacteria has higher tendency to convert most heavy metal in contaminated soil. This finding is agreeable to the results reported by previous bioremediation set-up, for heavy metal contaminated sites [11], [12].

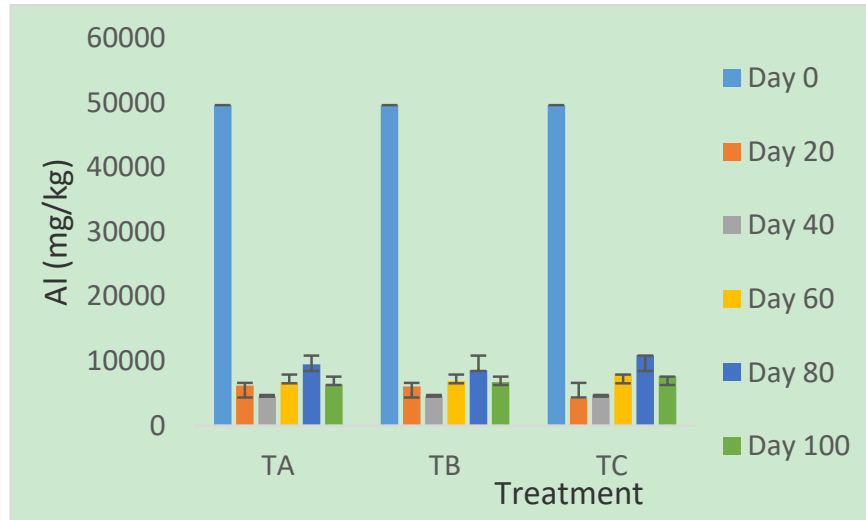

Fig. 4. Aluminium concentration across time with different treatments.

Also, Treatment A recorded the highest removal rate for As $\left(0.01270\right.$ day $\left.^{-1}\right)$ and $\mathrm{Ni}\left(0.00709\right.$ day- $\left.^{-1}\right)$. Treatment B recorded slightly low removal compared to Treatment B for $\mathrm{As}$, $\mathrm{Cu}$ and $\mathrm{Ni}$, but display higher removal rate among the three treatments for Zinc. The removal rate of Zn with Treatment B was 0.007 day $^{-1}$. Treatment $\mathrm{C}$ reported to have the lowest removal for all the four metals.

Table 4. Heavy Metal Removal Rate for Different Treatment (DAY-1)

\begin{tabular}{llll}
\hline \hline Metal & Treatment A & Treatment B & Treatment C \\
\hline $\mathbf{A s}$ & 0.01270 & 0.01120 & 0.00935 \\
$\mathbf{N i}$ & 0.00709 & 0.00617 & 0.00580 \\
$\mathbf{Z n}$ & 0.00647 & 0.00700 & 0.00290 \\
$\mathbf{A l}$ & 0.02 & 0.0199 & 0.0187 \\
\hline \hline
\end{tabular}

\section{Conclusions}

Heavy metal contamination is widespread in leachate contaminated soil due to poor waste management system at the non - sanitary landfills. This contributes to high amount of heavy metals above the prescribed limit. Certain microorganisms have the availability to survive and transform heavy metals to less toxic forms. From this study, it can be concluded that proteobacteria have higher potential for remediating heavy metal in a contaminated soil. Proteobacteria significantly removed As, $\mathrm{Ni}$ and $\mathrm{Al}$ at higher rate as compared to treatment with non-proteo bacteria. Nevertheless, the addition of bacterial groups to contaminated soil has higher capacity to remove metals from contaminated soil than those without any bacterial amendment.

\section{Acknowledgment}

The authors wish to acknowledge University of Malaya Research Grant (RP011A-14SUS) and Centre of Research Grant Management (PG070-2014B) for providing fund for this research. Also, we appreciate the management of Taman Beringin Landfills and Kuala Lumpur City Hall for the support during the research activities.

\section{References}

[1] Bashir, M. J. K., et al. (2009). Landfill leachate treatment by electrochemical oxidation. Waste Management, 29, 2534-2541. 
[1] Emenike, C. U., et al. (2012). Characterization and toxicological evaluation of leachate from closed sanitary landfill. Waste Management and Research, 30, 888-897.

[2] Jaishankar, M., et al. (2014). Biosorption of few heavy metal ions using agricultural wastes. Journal of Environment Pollution and Human Health, 2(1), 1-6.

[3] Nagajyoti, P. C., et al. (2010). Sreekanth. Heavy metals, occurrence and toxicity for plants: A review. Environental Chemistry Letter, 8(3), 199-216.

[4] Singh, M. R. (2007). Impurities-heavy metals: IR perspective. Retrieved from the website: http://www.usp.org/pdf/EN/meetings/asMeetingIndia/2008Session4track1.pdf

[5] Jayanthi, B., et al. (2016). Selected microbial diversity of contaminated landfill soil of Peninsular Malaysia and the behavior towards heavy metal exposure. Catena, 147, 25-31.

[6] Emenike, C. U., et al. (2016). Blending Bacillus sp., Lysinibacillus sp. and Rhodococcus sp. for optimal reduction of heavy metals in leachate contaminated soil. Environmental Earth Science, 75(26), 1-8.

[7] Gadd, G. M. (2000). Bioremedial potential of microbial mechanisms of metal mobilization and immobilization. Current. Opinion on Biotechnology, 11, 271-279.

[8] Kirpichtchikova, T. A., et al. (May 2006). Speciation and solubility of heavy metals in contaminated soil using X-ray microfluorescence, EXAFS spectroscopy, chemical extraction, and thermodynamic modelling. Geochimica et Cosmochimica Acta, 70(9), 2163-2190.

[9] Kuddus, M., et al. (October 2013). Production of laccase from newly isolated Pseudomonas putida and its application in bioremediation of synthetic dyes and industrial effluents. Biocatalysis and Agricultural Biotechnology, 2(4), 333-338.

[10] Guarino, C., et al. (March 2017). Assessment of three approaches of bioremediation (Natural Attenuation, Landfarming and Bioagumentation - Assisted Landfarming) for a petroleum hydrocarbons contaminated soil. Chemosphere, 170, 10-16.

[11] Alvarez, A., et al. (January 2017). Actinobacteria: Current research and perspectives for bioremediation of pesticides and heavy metals. Chemosphere, 166, 41-62.

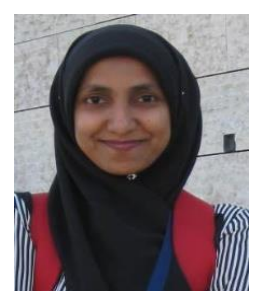

Fauziah Shahul Hamid obtained her PhD in waste management from University of Malaya, Kuala Lumpur, Malaysia. Currently, she is a senior lecturer in the Institute of Biological Sciences, Faculty of Science, University of Malaya, Kuala Lumpur, Malaysia. She is also the coordinator of master of technology (environmental management) and the head of Center for Research in Waste Management, in the university.

Her main research scope is environmental microbiology which focus on bioremediation studies of PAH, POPs, microplastics and heavy metal. She had published numerous articles in refereed journals (ISI and SCOPUS) and several chapters in books.

Dr Fauziah also is the member of International Solid Waste Association (ISWA) and a life member of Malaysian Society of Waste Management and Environment. 